\title{
PENGARUH PENAMBAHAN EKSTRAK KULIT BUAH MANGGIS (Garcinia mangostana L.) TERHADAP KARAKTERISTIK JELLY DRINK
}

Effect Of Skin Fruit Mangosteen Addition (Garcinia Mangostana L.) on Characteristics Jelly Drink

\author{
Nada Ulfa ${ }^{1)}$, Ni Luh Ari Yusasrini2), Putu Timur Ina ${ }^{2)}$ \\ ${ }^{1)}$ Mahasiswa Program Studi Ilmu dan Teknologi Pangan, Fakultas Teknologi Pertanian, Universitas Udayana \\ ${ }^{2)}$ Dosen Program Studi Ilmu dan Teknologi Pangan, Fakultas Teknologi Pertanian, Universitas Udayana \\ Kampus Bukit Jimbaran, Badung-Bali
}

\begin{abstract}
This research aimed was to identify the effect of mangosteen skin extract addition towards the characteristics of jelly drink and also to identify the precise of jelly drink with the best characteristics. This reseach used Completely Randomized Design (CRD) with the treatment of adding mangosteen skin which consists of six levels; $10 \mathrm{~g}, 20 \mathrm{~g}, 30 \mathrm{~g}, 40 \mathrm{~g}$, $50 \mathrm{~g}$, 60g. Each treatment was repeated 3 times, so it resulted in 18 experimental units. The data were then analyzed with the Analysis of Variance method and if the treatment had an effect on the variable, the Duncan test was performed. The results showed that mangosteen skin extract siginificantly affected the level of vitamin $C$, antioxidant activity, hedonic (color and overall acceptance), scor (color and taste), Non significant effect to taste and the overall acceptance of mangosteen skin extract jelly drink. The addition of $60 \mathrm{~g}$ mangosteen skin resulted in the best characteristic according the following criteria: 54;85 mg AAE/g vitamin C, 96;81\% antioxidant activity, red color and liked, texture liked, taste netral and rather tight, and overall acceptance liked.
\end{abstract}

Keyword: mangosteen skin, jelly drink, characteristics, antioxidant

\section{PENDAHULUAN}

Jelly drink adalah produk minuman yang berbentuk gel dan memiliki karakteristik berupa cairan kental yang mudah disedot. Selain itu, jelly drink memiliki karakteristik gel yang berbeda dari produk jelly pada umumnya. Gel dari jelly drink lebih lunak (halus) dan teksturnya tidak kokoh, sehingga saat dikonsumsi lebih mudah disedot, tetapi saat dimulut masih dapat dirasakan tekstur gelnya. Jelly drink merupakan salah satu alternatif pangan ringan yang banyak disukai oleh anakanak, remaja bahkan dewasa.

Bahan baku dalam pembuatan jelly drink umumnya menggunakan ekstrak buah serta dengan bahan pendukung diantaranya tepung jeli, sukrosa, asam sitrat, dan pewarna sintetis (Noer, 2006). Menurut Prananjaya (2007), minuman jeli atau jelly drink dapat menjadi minuman fungsional karena kaya akan serat dan bersifat penunda lapar.

\footnotetext{
*Korespondensi Penulis:

E-mail: nadaulfa144@gmail.com ${ }^{1)}$
}

Indonesia cukup banyak memiliki bahan pangan alami yang dapat dimanfaatkan menjadi olahan jelly drink salah satunya yaitu kulit buah manggis. Bagian kulit buah manggis dapat menghasilkan zat warna alami yang digunakan sebagai pewarna makanan dan sekaligus mengandung sumber antioksidan (Supiyanti dkk., 2010). Menurut Permana (2010), kulit buah manggis dikategorikan sebagai limbah yang merupakan sumber antioksidan serta mengandung $62,05 \%$ air; $1,01 \%$ abu; $0,63 \%$ lemak; $0,71 \%$ protein; $1,17 \%$ gula; dan $35,61 \%$ karbohidrat. Menurut penelitian Miryanti dkk., (2011), kulit buah manggis memiliki aktivitas antioksidan sebesar $82,97 \%$. Kulit buah manggis memiliki beberapa senyawa antioksidan seperti xanton, fenol, antosianin, dan vitamin C (Anon, 2011)

Kulit buah manggis juga memiliki kandungan vitamin $\mathrm{C}$. Vitamin $\mathrm{C}$ merupakan suatu molekul organik yang sangat diperlukan oleh tubuh untuk proses metabolisme dan dapat memelihara kesehatan. 
Vitamin C dikenal sebagai asam askorbat dan merupakan antioksidan yang melindungi tubuh dari radikal bebas dan membantu memperbaiki kerusakan jaringan (Waluyo dan Putra, 2010). Menurut Iswari (2011), asam askorbat yang paling besar adalah pada kulit buah manggis yaitu $70-75 \%$ sedangkan daging buah hanya $10-15 \%$.

Pembuatan jelly drink ekstrak kulit buah manggis merupakan salah satu upaya untuk memperoleh produk yang mengadung antioksidan dan vitamin $\mathrm{C}$ sehingga jelly drink ekstrak kulit buah manggis dapat dijadikan pangan fungsional. Proses pembutan jelly drink secara umum meliputi proses pencucian, penghancuran, penyaringan, pengukuran $\mathrm{pH}$, pencampuran, pemasakan, pendinginan, dan pengemasan (Setiawati, 2017). Jelly drink kulit buah manggis dapat diperoleh dengan cara merebus sejumlah kulit buah manggis dalam air panas, kemudian air ekstrak kulit buah manggis disaring dan dilakukan pengolahan lebih lanjut sehingga menghasilkan produk jelly drink.

Hasil penelitian (Wati, 2017) dalam pembuatan jelly drink dari sari buah duwet menyatakan bahwa semakin tinggi penambahan sari buah duwet menghasilkan aktivitas antioiksidan yang tinggi. Penelitian terkait penambahan kulit buah manggis terhadap karakteristik jelly drink belum pernah dilakukan. Penelitian ini dilakukan untuk mengetahui penambahan kulit buah manggis yang tepat dalam pembuatan jelly drink sehingga menghasilkan produk yang memiliki karakteristik terbaik.

\section{METODE PENELITIAN}

\section{Tempat dan Waktu Penelitian}

Penelitian ini dilaksanakan di Laboratorium Pengolahan Pangan dan Laboratorium Analisis Pangan, Laboratorium Biokimia dan Nutrisi, serta Laboratorium Rekayasa Proses dan Pengendalian Mutu. Fakultas Teknologi Pertanian, Universitas
Udayana. Waktu pelaksanaan Juli 2018 sampai Agustus 2018.

\section{Alat dan Bahan}

Bahan yang akan digunakan dalam penelitian ini adalah kulit buah manggis lokal (Garcinia mangostana L) yang didapat dari pasar tradisional di daerah Jimbaran, Bali, konyaku merek red man dari pembelian online, asam sitrat dari UD.Fenny, Denpasar, gula pasir pasir merek dagang "Gulaku". Bahan kimia yang digunakan dalam melakukan analisis meliputi, metanol, aquades, Sodium Fosfat, Amonium Molibdat, Asam Askorbat, $\mathrm{H}_{2} \mathrm{SO}_{4}$, dan larutan DPPH (1,1-diphenyl-2-picrylhydrazyl) 0,004\%.

Alat yang digunakan dalam proses pengolahan jelly drink kulit buah manggi yaitu, sendok, pisau, panci, gelas ukur, timbangan analitik (Shimadzu), kompor gas (quantum), wadah, sedotan. Sedangkan alat untuk menganalisi yaitu, timbangan analitik (Shimadzu), labu ukur (pyrex), corong, kertas saring, thermometer, pipet tetes, pipet mikro (Socorex), pipet volume (Pyrex), erlenmeyer (pyrex), vortex (Maxi Mix II Type 367000), tabung reaksi (pyrex), water bath, alumunium foil (Klin Pak) dan spektrofotometer (Thermo Scientific Genesys 10S UV-Vis).

\section{Rancangan Percobaan}

Rancangan yang digunakan pada penelitian ini adalah Rancangan Acak Lengkap (RAL) yang terdiri dari 6 perlakuan dan 3 kali ulangan sehingga diperoleh 18 unit percobaan. Taraf perlakuan dalam pembuatan jelly drink ekstrak kulit buah manggis pada penelitian ini adalah sebagai berikut:

$\mathrm{P} 1$ = Penambahan Kulit Buah Manggis $10 \mathrm{~g}$

$\mathrm{P} 2=$ Penambahan Kulit Buah Manggis $20 \mathrm{~g}$

P3 = Penambahan Kulit Buah Manggis $30 \mathrm{~g}$

P4 = Penambahan Kulit Buah Manggis $40 \mathrm{~g}$

$\mathrm{P} 5=$ Penambahan Kulit Buah Manggis $50 \mathrm{~g}$

P6 = Penambahan Kulit Buah Manggis $60 \mathrm{~g}$

Data yang diperoleh dianalisis dengan

sidik ragam dan apabila terdapat pengaruh 
terhadap variabel yang diamati dilanjutkan dengan uji uji Duncan's Multiple Range Test (DMRT) (Gomez dan Gomez, 1995).

\section{Pelaksanaan Penelitian}

Proses pembuatan jelly drink kulit buah manggis meliputi beberapa tahap, yaitu:

1. Pembuatan ekstrak kulit buah manggis

Tahap satu pembuatan ekstrak kulit buah manggis mengacu pada (Irmaningtyas, 2012) yang dimodifikasi. Proses pembuatan ekstrak kulit buah manggis dimulai dengan pencucian kulit buah manggis. Kulit buah manggis dipotong kecil-kecil, lalu ditimbang sesuai perlakuan. Air sebanyak $500 \mathrm{ml}$ dipanaskan hingga suhu $90^{\circ} \mathrm{C}$, dimasukan kulit buah manggis kedalam air rebusan selama \pm 10 menit. Setelah direbus disaring lalu didapatkan ekstrak kulit buah manggis.

2. Pembuatan jelly drink ekstrak kulit buah manggis

Tahap dua pembuatan jelly drink kulit buah manggis mengacu pada (Setiawati, 2017) yang dimodifikas. Diambil sebanyak $100 \mathrm{ml}$ dari masing-masing perlakuan untuk dijadikan jely drink, kemudian dicampur dengan $0,1 \mathrm{~g}$ konyaku, $0,2 \mathrm{~g}$ asam sitrat dan $15 \mathrm{~g}$ gula pasir. Selanjutnya dipanaskan dan diaduk sampai suhu $\pm 80^{\circ} \mathrm{C}$ selama 5 menit. Larutan jelly drink ekstrak kulit buah manggis yang sudah homogen dituang dalam wadah sambil diaduk, kemudian didinginkan sampai terbentuk jelly drink.

\section{Variabel yang Diamati}

Variabel yang diamati dalam penelitian ini meliputi, kadar vitamin $\mathrm{C}$ dengan metode spektrofotometer (Vuong dkk., 2014), aktivitas antioksidan menggunakan metode 2.2-diphenyl-1-picrylhydrazyl (DPPH) (Tsai dkk., 2008), sifat sensoris yang meliputi tekstur, warna, rasa, dan penerimaan keseluruhan (uji hedonik) serta warna dan rasa (uji skor) (Soekarto, 1985).

\section{HASIL DAN PEMBAHASAN}

\section{Hasil Analisis Bahan Baku}

Hasil analisis dari kadar vitamin $\mathrm{C}$ dan aktivitas antioksidan kulit buah manggis dapat dilihat pada Tabel 1.

Berdasarkan tabel 1 kadar vitamin $\mathrm{C}$ pada bahan baku kulit buah manggis didapatkan hasil yang cukup tinggi yaitu sebesar $96,12 \mathrm{mg} / \mathrm{g}$, sedangkan menurut penelitian (Susanti dkk., 2018) kadar vitamin C pada kulit buah manggis sebesar 44,4 mg/g. Hal ini dikarenakan adanya beberapa perbedaam seperti, pengaruh varietas yang berbeda, suhu penyimpanan, lama penyimpanan, dan sifat vitamin $\mathrm{C}$ yang mudah teroksidasi (Supyanti dkk., 2010).

Aktivitas antioksidan kulit buah manggis berdasarkan tabel 2 memiliki presentase peredaman radikal bebas sebesar $98,51 \%$, nilai aktivitas antioksidan tersebut tidak jauh berbeda dengan penelitian yang telah dilakukan oleh (Miryanti dkk, 2011) yaitu sebesar $82,97 \%$.

\section{Hasil Analisis Jelly drink Kulit Buah Manggis}

Hasil analisis kadar vitamin c dan aktivitas antioksidan dari jelly drink ekstrak kulit buah manggis terdapat pada Tabel 2.

\section{Kadar Vitamin C}

Hasil analisis ragam jelly drink ekstrak kulit buah manggis menunjukkan bahwa perlakuan penambahan kulit buah manggis berpengaruh sangat nyata $(\mathrm{P}<0,01)$ terhadap vitamin $\mathrm{C}$ jelly drink ekstrak kulit buah manggis. Tabel 2 menunjukkan bahwa nilai rata-rata kadar vitamin $\mathrm{C}$ terendah terdapat pada penambahan $10 \mathrm{~g}$ kulit buah manggis (P1) dengan kandungan 15,77 mg AAE/g, sedangkan nilai rata-rata kadar vitamin $\mathrm{C}$ tertinggi terdapat pada penambahan $60 \mathrm{~g}$ kulit buah manggis (P6) dengan kandungan 54,85 mg AAE/g. 
Tabel 1. Nilai rata-rata kadar vitamin $\mathrm{C}$ dan aktivitas antioksidan dari kulit buah manggis

\begin{tabular}{lc}
\multicolumn{1}{c}{ Komponen } & Kulit Buah Manggis \\
\hline Vitamin C (mg AAE/g) & $96,12 \pm 1,105$ \\
Aktivitas Antioksidan (\%) & $98,51 \pm 0,124$ \\
\hline
\end{tabular}

Tabel 2. Nilai rata-rata kadar vitamin $\mathrm{C}$ dan aktivitas antioksidan jelly drink kulit buah manggis

\begin{tabular}{ccc}
\hline Penambahan Kulit & Kadar Vitamin C (mg AAE/g) & Aktivitas Antioksidan (\%) \\
\hline (P1) & $15,77 \pm 0,304 \mathrm{f}$ & $36,87 \pm 0,249 \mathrm{f}$ \\
(P2) & $21,28 \pm 0,291 \mathrm{e}$ & $54,21 \pm 0,692 \mathrm{e}$ \\
(P3) & $32,25 \pm 1,496 \mathrm{~d}$ & $79,07 \pm 0,309 \mathrm{~d}$ \\
(P4) & $42,87 \pm 0,628 \mathrm{c}$ & $91,09 \pm 0,433 \mathrm{c}$ \\
(P5) & $46,27 \pm 1,269 \mathrm{~b}$ & $95,25 \pm 0,215 \mathrm{~b}$ \\
(P6) & $54,85 \pm 1,091 \mathrm{a}$ & $96,81 \pm 0,438 \mathrm{a}$ \\
\hline
\end{tabular}

Keterangan: Huruf yang sama dibelakang nilai rata-rata pada kolom yang sama menunjukkan perlakuan berbeda tidak nyata $(\mathrm{P}>0,05)$

Vitamin $\mathrm{C}$ adalah salah satu antioksidan alami. Kadar vitamin C jelly drink ekstrak kulit buah manggis dipengaruhi oleh jumlah penambahan kulit buah manggis. Semakin banyak kulit buah manggis yang digunakan, semakin tinggi kadar vitamin C pada jelly drink. Hal ini sesuai dengan penelitian Setiawati (2017) terkait pemanfaatan limbah kulit anggur lokal dalam pembuatan jelly drink semakin banyak jumlah penambahan bahan baku yang digunakan maka akan mengakibatkan, semakin bertambahnya kadar vitamin C pada produk jelly drink yang dihasilkan.

Kadar vitamin C pada jelly drink mengalami penurunan bila dibandingkan dengan bahan baku. Penurunan kadar vitamin C dapat terjadi karena adanya proses pemanasan pada saat proses pembuatan jelly drink. Kestabilan vitamin $\mathrm{C}$ pada suatu bahan juga dipengaruhi oleh berbagai faktor. Beberapa faktor yang mempengaruhi stabilitas vitamin $\mathrm{C}$ pada produk yaitu, vitamin $\mathrm{C}$ larut air, mudah teroksidasi dan proses tersebut dipercepat oleh panas, sinar, alkali (Winarno, 2008).

\section{Aktivitas Antioksidan}

Hasil analisis ragam jelly drink ekstrak kulit buah manggis menunjukkan bahwa perlakuan penambahan kulit buah manggis berpengaruh sangat nyata $(\mathrm{P}<0,01)$ terhadap aktivitas antioksidan jelly drink ekstrak kulit buah manggis. Tabel 2 menunjukkan bahwa nilai rata-rata aktivitas antioksidan terendah terdapat pada penambahan $10 \mathrm{~g}$ kulit buah manggis (P1) dengan nilai 36,87\%, sedangkan nilai rata-rata aktivitas antioksidan tertinggi terdapat penambahan $60 \mathrm{~g}$ kulit buah manggis (P6) dengan nilai 96,81\%.

Antioksidan adalah substansi yang diperlukan tubuh untuk menetralisir radikal bebas dan mencegah kerusakan yang ditimbulkan oleh radikal bebas terhadap sel normal, protein dan lemak (Waji dan Sugrani, 2009). Penelitian melaporkan bahwa ekstrak kulit buah manggis berpotensi sebagai antioksidan (Moongkarndi dkk., 2004). Beberapa senyawa yang terdapat pada kulit buah manggis yaitu, xanton, mangostin, garsinon, flavonoid dan tanin. Senyawasenyawa tersebut diduga berperan dalam menentukan aktivitas antioksidan pada kulit buah manggis. Hal ini sesuai dengan penelitian Mansur (2017) terkait pengaruh perbedaan jumlah kulit manggis terhadap kualitas permen jelly kulit manggis (Garcinia Mangostana L.) semakin banyak jumlah kulit manggis yang digunakan maka semakin tinggi kandungan antioksidannya. 


\section{Evaluasi Sensoris}

Evaluasi sifat sensori jelly drink ekstrak kulit buah manggis dilakukan uji hedonik terhadap warna, tekstur, rasa dan penerimaan keseluruhan serta uji skoring terhadap warna dan rasa jelly drink ekstrak kulit buah manggis . Nilai rata-rata uji sensoris dapat dilihat pada Tabel 3 .

\section{Warna}

Hasil analisis ragam jelly drink ekstrak kulit buah manggis menunjukkan bahwa penambahan kulit buah manggis pada jelly drink berpengaruh sangat nyata $(\mathrm{P}<0,01)$ terhadap warna dengan pengujian hedonik dan skor jelly drink ekstrak kulit buah maggis. Nilai rata-rata dari uji hedonik warna jelly drink ekstrak kulit buah maggis pada Tabel 3 menunjukkan bahwa nilai rata-rata tertinggi diperoleh pada jelly drink dengan penambahan kulit buah manggis 60g (P6) dengan kriteria suka serta berbeda tidak nyata dengan P5, sedangkan nilai rata-rata terendah diperoleh pada jelly drink dengan penambahan kulit buah manggis $10 \mathrm{~g}$ (P1) dengan kriteria netral serta berbeda tidak nyata dengan $\mathrm{P} 2$. Warna jelly drink ekstrak kulit buah manggis dapat dipengaruhi oleh penambahan kulit buah manggis karena semakin banyak penambahan kulit buah manggis, produk yang dihasilkan akan semakin gelap sehingga dapat mempengaruhi tingkat kesukaan panelis.

Nilai rata-rata uji skor warna jelly drink pada Tabel 3 menunjukkan bahwa nilai ratarata tertinggi diperoleh pada jelly drink dengan penambahan kulit buah manggis $50 \mathrm{~g}$ (P5) dengan kriteria warna merah serta berbeda tidak nyata dengan P6, sedangkan nilai ratarata terendah diperoleh pada jelly drink dengan penambahan kulit buah manggis $10 \mathrm{~g}$ (P1) dengan kriteria warna oranye.

Semakin tinggi penambahan kulit buah manggis maka warna jelly drink ekstrak kulit buah manggis akan semakin merah. Hal ini disebabkan karena tingginya penambahan jumlah kulit buah manggis yang digunakan. Kulit manggis mengandung sejumlah pigmen yang berasal dari dua metabolit, yaitu mangostin dan $\beta$-mangostin yang jika diekstrak dapat menghasilkan bahan pewarna alami berupa antosianin. Antosianin dalam kulit manggis dapat menghasilkan warna merah, ungu dan biru (Aji, dkk., 2013). Menurut Supyanti, dkk (2010) bagian kulit buah manggis dapat dimanfaatkan sebagai penghasil zat warna alami yang dapat digunakan sebagai pewarna makanan dan dimanfaatkan sebagai antioksidan.

\section{Tekstur}

Hasil analisis ragam jelly drink ekstrak kulit buah manggis menunjukkan bahwa penambahan kulit buah manggis berpengaruh tidak nyata $(\mathrm{P}>0,05)$ terhadap nilai rata-rata tekstur dengan pengujian hedonik dari jelly drink kulit buah manggis. Tabel 3 menunjukkan nilai rata-rata tekstur uji hedonik jelly drink berkisar antara netral sampai suka. Hal ini dikarenakan pembentukan tekstur pada jelly drink dipengaruhi oleh konyaku. Pada penelitian ini, konyaku yang digunakan tidak berbeda antar perlakuan sehingga tidak mempengaruhi tekstur dari masing-masing jelly drink. Konyaku merupakan tepung yang terbuat dari umbi tanaman iles-iles atau konjak (Amorphopallus konjac) yang bersifat gel dengan komponen utama berupa glukomanan. Glukomanan merupakan zat pembentuk gel (gelling agents) (Supriyati, 2002). Glukomanan dapat membantu mengurangi tingkat sineresis. Sineresis adalah suatu fenomena dimana keluarnya cairan dari gel. Pencampuran karagenan dan tepung konyaku dapat menghasilkan gel elastis yang cocok dengan karakteristik minuman jeli. (Mariana dkk, 2008). 
Tabel 3 Nilai rata-rata uji sensoris ekstrak jelly drink kulit buah manggis

\begin{tabular}{ccccccc}
\hline \multirow{2}{*}{ Perlakuan } & \multicolumn{6}{c}{ Nilai Rata-Rata Uji Sensoris } \\
\cline { 2 - 7 } & \multicolumn{2}{c}{ Warna } & Tekstur & Rasa & Penerimaan Keseluruhan \\
\cline { 2 - 7 } & hedonik & skor & hedonik & hedonik & skor & hedonik \\
\hline P1 & $2,80 \mathrm{c}$ & $1,40 \mathrm{e}$ & $3,20 \mathrm{a}$ & $3,93 \mathrm{a}$ & $3,67 \mathrm{a}$ & $3,27 \mathrm{~b}$ \\
P2 & $3,27 \mathrm{bc}$ & $2,40 \mathrm{~d}$ & $33,3 \mathrm{a}$ & $3,53 \mathrm{a}$ & $3,27 \mathrm{ab}$ & $3,33 \mathrm{~b}$ \\
P3 & $3,40 \mathrm{~b}$ & $3,00 \mathrm{~cd}$ & $3,40 \mathrm{a}$ & $3,47 \mathrm{a}$ & $3,13 \mathrm{ab}$ & $3,53 \mathrm{~b}$ \\
P4 & $3,53 \mathrm{~b}$ & $3,53 \mathrm{bc}$ & $3,53 \mathrm{a}$ & $3,87 \mathrm{a}$ & $2,53 \mathrm{bc}$ & $3,73 \mathrm{ab}$ \\
P5 & $4,13 \mathrm{a}$ & $3,93 \mathrm{a}$ & $3,73 \mathrm{a}$ & $3,53 \mathrm{a}$ & $2,20 \mathrm{c}$ & $3,73 \mathrm{ab}$ \\
P6 & $4,40 \mathrm{a}$ & $4,33 \mathrm{ab}$ & $3,93 \mathrm{a}$ & $3,80 \mathrm{a}$ & $2,13 \mathrm{c}$ & $4,13 \mathrm{a}$ \\
\hline
\end{tabular}

Keterangan

: Huruf yang sama dibelakang nilai rata-rata pada kolom yang sama menunjukkan perlakuan berbeda tidak nyata $(\mathrm{P}>0,05)$.

Kriteria hedonik $\quad: 1$ (sangat tidak suka), 2 (tidak suka), 3 (netral), 4 (suka), 5 (sangat suka)

Nilai skoring warna : 1 (oranye), 2 (oranye kemerahan), 3 (merah keoranyean), 4 (merah), 5 (merah tua)

Nilai skoring rasa $\quad: 1$ (sangat sepat), 2 (sepat), 3 (agak sepat), 4 (agak tidak sepat), 5 (tidak sepat)

\section{Rasa}

Hasil analisis ragam jelly drink ekstrak kulit buah manggis menunjukkan bahwa penambahan kulit buah manggis pada jelly drink kulit buah manggis berpengaruh tidak nyata $(\mathrm{P}>0,05)$ terhadap rasa dengan pengujian hedonik dan berpengaruh sangat nyata $(\mathrm{P}<0,01)$ dengan pengujian skor dari jelly drink kulit manggis. Tabel 3 menunjukkan nilai ratarata rasa dengan pengujian hedonik jelly drink adalah antara netral sampai dengan suka. Hal ini dikarenakan tingkat penerimaan terhadap rasa sepat masih dapat diterima oleh panelis

Nilai rata-rata rasa dengan pengujian skor terhadap jelly drink kulit buah manggis pada Tabel 3 menunjukkan bahwa nilai ratarata tertinggi diperoleh pada jelly drink dengan penambahan kulit buah manggis $10 \mathrm{~g}$ (P1) dengan kriteria agak tidak sepat serta berbeda tidak nyata dengan $\mathrm{P} 2$ dan $\mathrm{P} 3$, sedangkan nilai rata-rata terendah diperoleh pada jelly drink dengan penambahan kulit buah manggis $60 \mathrm{~g}$ (P6) dengan kriteria agak sepat serta berbeda tidak nyata dengan P4 dan P5. Tingkat kesukaan panelis terhadap rasa jelly drink kulit buah manggis disebabkan oleh tanin yang terkandung dalam kulit buah manggis sehingga memberikan rasa sepat (Pratama dkk., 2015).

\section{Penerimaan Keseluruhan}

Hasil analisis ragam menunjukkan bahwa penambahan kulit buah manggis pada jelly drink berpengaruh nyata $(<0,05)$ terhadap penerimaan keseluruhan jelly drink kulit buah manggis. Tabel 3 menunjukkan bahwa nilai rata-rata tertinggi diperoleh pada jelly drink dengan penambahan kulit buah manggis $60 \mathrm{~g}$ (P6) dengan kriteria suka serta berbeda tidak nyata dengan P4 dan P5, sedangkan nilai ratarata terendah diperoleh pada jelly drink dengan penambahan kulit buah manggis $10 \mathrm{~g}$ (P1) dengan kriteria netral serta berbeda tidak nyata dengan P2 dan P3. Nilai rata-rata kesukaan keseluruhan tersebut menunjukkan bahwa jelly drink kulit buah manggis dapat diterima cukup naik oleh panelis.

\section{KESIMPULAN DAN SARAN}

Berdasarkan hasil penelitian yang telah dilakukan dapat diambil kesimpulan sebagai berikut:

1. Penambahan ekstrak kulit buah manggis yang berbeda berpengaruh terhadap kadar vitamin $\mathrm{C}$, aktivitas antioksidan, aktivitas antioksidan, hedonik (warna dan 
penerimaan keseluruhan), skor (warna dan rasa), berpengaruh tidak nyata terhadap hedonik (tekstur dan rasa).

2. Perlakuan penambahan ekstrak kulit buah manggis sebanyak $60 \mathrm{~g}$ menghasilkan karakteristik terbaik pada pembuatan jelly drink kulit buah manggis dengan kriteria kadar vitamin C 54,85 mg AAE/g, aktivitas antioksidan $96,8 \%$, warna merah dan suka, tekstur suka, rasa netral dan agak sepat, serta penerimaan keseluruhan disukai.

\section{Saran}

Berdasarkan penelitian diatas disarankan untuk melakukan penelitian lebih lanjut mengenai umur simpan jelly drink kulit buah manggis dengan penambahan kulit buah manggis sebesar $60 \mathrm{~g}$ sehingga menghasilkan jelly drink dengan karakteristik terbaik.

\section{DAFTAR PUSTAKA}

Aji, A., Meriata., dan A. S. Ferani. 2013. Pembuatan Pewarna Makanan Dari Kulit Buah Manggis Dengan Proses Ekstraksi. Jurnal Teknologi Kimia Unimal. Universitas Malikussaleh. $2(2): 1-5$

Anonimus. 2011. Kandungan Nutrisi Kulit Buah Manggis. Balai Besar Penelitian dan Pengembangan Pascapanen Pertanian, Bogor.

Gomez, K. A. dan A. A. Gomez. 1995. Prosedur Statistik Untuk Penelitian Pertanian. UI Press, Jakarta.

Irmaningtyas, I. N. 2012. Pemanfaatan Kulit Buah Manggis dalam Proses Pembuatan Sirup Kulit Buah Manggis yang Mengandung Anioksidan. Laporan Tugas Akhir. Jurusan Teknologi Hasil Pertanian. Fakultas Pertanian. Universitas Sebelas Maret Surakarta.
Mansur, A. 2017. Pengaruh Perbedaan Massa Kulit Buah Manggis Terhadap Kualitas Permen Jelly Kulit Manggis (Garcinia mangostana L). Jurnal Gemawisata. Sekolah Tinggi Ilmu Ekonomi Pariwisata. Semarang. 13(1):14-16

Mariana, I., S.B. Widjanarko, dan S.N. Wulan. 2008. Studi Pembuatan Minuman Jeli Wortel dengan Tepung konyaku dan Karagenan sebagai Bahan Pembentuk Gel Ditinjau dari Sifat Fisik, Kimia dan Organoleptik. https://simonbwidjanarko.wordpress.c om/2008. Diakses pada tanggal 26 Februari 2018.

Miryanti, Y.I.P.A, Lanny, S., Kurniawan, B. dan Stephen, I. 2011. Ekstraksi Antioksidan Dari Kulit Buah Manggis (Garcinia mangostana L). Lembaga Penelitian dan Pengabdian Kepada Masyarakat. Universitas Katolik Parahyangan. Bandung

Moongkarndi, P., N. Kosem, S. Kaslungka, O. Luanratana, N. Pongpan, dan N. Neungton. 2004. Antiproliferation, Antioxidation and Induction of Apoptosis by Garcinia mangostana (mangosteen) on SKBR3 human breast cancer cell line. Ethnopharmacol Jurnal. 90 (1): 161 166.

Noer, H. 2006. Hidrokoloid dalam Pembuatan Jelly Drink. Food Review. 1(2).

Permana, A.W. 2010, Kulit Buah Manggis dapat Menjadi Minuman Instan Kaya Antioksidan. Warta Litbang Deptan. 32(2):3.

Pranajaya, D. 2007. Pendugaan Sisa Umur Simpan Minuman Jelly di Pasaran. Skripsi. Intitut Pertanian Bogor, Bogor. 
Pratama, N., U. Pato, dan Yusmarini. 2015. Kajian Pembuatan Teh Kombucha Dari Kulit Buah Manggis (Garcinia mangostana L). JOMFAPERTA. Fakultas Pertanian, Universitas Riau Indonesia. 2(2)

Setiawati, I. 2017. Pemanfaatan Kulit Anggur Lokal dalam Pembuatan Jelly Drink. Skripsi. Jurusan Ilmu dan Teknologi Pangan, Fakultas Teknologi Pertanian, Universitas Udayana.

Soekarto, S.T. 1985. Penilaian Organoleptik untuk Industri Pangan dan Hasil Pertanian. Bhratara Karya Aksara, Jakarta.

Supriyati, Y. 2002. Peningkatan Multiplikasi Tunas dan Induksi Akar Tanaman Ilesiles Melalui Kultur In Vitro. Available from

http://biogen.litbang.deptan.go.id/ terbitan/prossiding/fulltextpdf/prosiding. Diakses pada tanggal 3 April 2018.

Supiyanti, W., Wulansari. D. E, dan Kusmita, L. 2010. Uji Aktifitas dan Penentuan Kandungan Antosianin Total Kulit Buah Manggis (Garcinia mangostana L). Sekolah Tinggi Ilmu Farmasi Yayasan Pharmasi. Semarang. 15(2)

Tsai, P.J., S. C. Wu, dan Y. K. Cheng. 2008. Role of Polyphenols in Antioxidant Capacity of Napiergrass from Different Growing Seasons. National Pingtung University of Technology and Science. 106(1): 27-32.

Vuong, Q.V., S. Hirun, T.L.K. Chuen, C.D. Goldsmith, M.C. Bowyer, A.C. Chalmers, P.A. Phillips dan C.J. Scarlett. 2014. Physicochemical Composition, Antioxidant and Antiproliferative Capacity of a Lilly Pilly (Syzygium paniculatum) Extract. Herbal Medicine. 4(3): 134-140.
Waji, R.A. dan A. Sugrani. 2009. Kimia Organik Bahan Alam, Flavonoid (Quercetin). Thesis. Program Studi Kimia, Fakultas Matematika Dan Ilmu Pengetahuan Alam, Universitas Hasanuddin, Makassar.

Waluyo dan Putra. 2010. Rahasia-Rahasia Keajaiban Kulit Buah Manggis Untuk Kesehatan Harian dan Terapi Penyakit Berat. Pustaka Baru Prees. Yogyakarta

Wati, A.F. 2017. Aplikasi Perbandingan Sari Buah Duwet (Syzygium cumini) dan Air Dalam Pembuatan Jelly Drink. Skripsi. Jurusan Ilmu dan Teknologi Pangan, Fakultas Teknologi pertanian, Universitas Udayana. Jimbaran.

Winarno, F.G. 2008. Kimia Pangan dan Gizi. Gramedia Pustaka Utama. Bogor. 